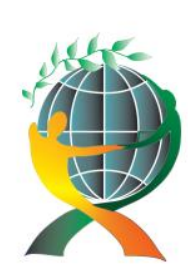

\author{
(online) $=$ ISSN $2285-3642$ \\ ISSN-L = $2285-3642$ \\ Journal of Economic Development, Environment and People \\ Volume 4, Issue 3, 2015
}

URL: http://jedep.spiruharet.ro

e-mail: office jedep@spiruharet.ro

\title{
Application of New Instruments to Increase Effectiveness of Implementation of Social Policies on Labour Market in Bulgaria
}

\author{
Venelin Terziev ${ }^{1}$, Ekaterina Arabska ${ }^{2}$ \\ ${ }^{1,2}$ University of Agribusiness and Rural Development
}

\begin{abstract}
Nowadays, public employment services face a number of urgent tasks as raising the employment rate and reducing the number of vacant jobs for which is difficult to find enough qualified workers. New realities on labour market and dynamic environment require adequate actions, rational and timely decision making and optimization of work. Dynamic changes in social environment impacting labour markets and activities of public employment services impose various tasks which implementation should be carefully planned, organized and controlled. To achieve that public employment services should take a more comprehensive look at the demand and supply of labour, considering the numerous transitions taking place constantly on the labour market and people's personal development. Improving processes and the quality of the administrative services in the Bulgarian employment agency is seen as a prerequisite for effective implementation of employment policies. The study presents opportunities for improving the quality of services offered in the Directorates "Labour Office" in the Republic of Bulgaria by introducing a process model and improvements in the capacity and efficiency of work in the field of labour mediation.
\end{abstract}

Keywords: employment, unemployment, process model, algorithm, efficiency

\section{JEL Codes: $\mathrm{O} 29$}

\section{Introduction}

In a market economy the rate of employment and unemployment of the economically active population is determined by the labour market, by market mechanisms regulating demand and supply of labour. The features of the economic development and the possible impacts on the labour market gradually becomes an inseparable part of the process of policy making on the labour market. In the early periods of the development of labour market its policies are aimed primarily at tackling the effects of economic reforms on employment, it is now when the policy has pronounced active character and is aimed at influencing processes or the formation of behaviour among target groups according to pre-planned targets

\footnotetext{
${ }^{1}$ E-mail address: terziev@skmat.com

${ }^{2}$ E-mail address: katya arabska@abv.bg
} 


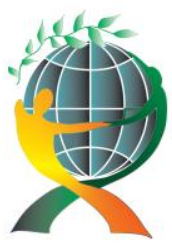

\author{
(online) $=$ ISSN $2285-3642$ \\ ISSN-L = $2285-3642$ \\ Journal of Economic Development, Environment and People \\ Volume 4, Issue 3, 2015 \\ URL: $\underline{\text { http://jedep.spiruharet.ro }}$ \\ e-mail: office jedep@spiruharet.ro
}

[4]. Functioning labour market in a country is an adequate mechanism of the market environment and policy increasingly based on existing relationships and interactions between the periods of development of the economy and the labour market. The adequacy and timeliness of the policy are crucial for the effective support of the changes in the parameters of labour market and economic development. The time delay effects and changes in its duration should not be ignored in order to develop preventive measures for timely response. The shortening of the period in which the effects of modern crisis transferred on the labour market, respectively the demand for labour, reflects not only the degree of elasticity of demand for labour to primary markets, but also the flexibility of the implemented policies [5]. This has focused attention on the flexibility of labour markets and opportunities through its increase to strengthen the mobility and adaptability of the workforce to rapidly changing labour demand.

Objectives and tasks of social policy in the regulation of the labour market productivity and employment are the following [6]:

- creation of all necessary conditions for economic growth, structural change in the industry to create new jobs for the employment of the economically active population;

- workforce flexibility, mobility in order to overflow freely between sectors, fields of application of employment and occupation, and also between the territories in the interest of growth of labour productivity and standard of living levels;

- connection of all parameters of demand and supply of labour, securing natural level of unemployment;

- assistance in job placement and social protection for the unemployed and socially vulnerable layers of the economically active population on the labour market;

- formation of a new motivation for highly productive labour of the individual;

- decent level of wages and income adequate to their qualifications, experience and the level of entrepreneurship;

- material interest and civil responsibility of the individual to maintain the standard of living of his family;

- elimination of the reasons and factors both external and domestic ones governing storage of underemployment and hidden unemployment.

An alignment of objectives and specifying the tasks of regulating relations in the labour market between all levels of government as well as its active agents is also necessary.

The competence of the central bodies of power are related to those to define and control the implementation of social guarantees on employment, securing the volume of centralized investments to deliver the nation-wide social programs, including programs for full employment, and storage jobs, career guidance and other cooperation with the corporate capital at his involvement in the process of investing in employment. Their place in the active policy on the labour market should also take regional bodies. Local authorities determine the status of the unemployed, reveal such citizens and provide them with specific assistance in job placement. In this connection, the group of measures for active policy on the labour market in order to support employment and the so-called "transitional forms" between unemployment and productive employment are therefore among the main goals to regulate the labour market. 


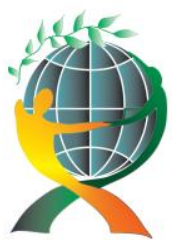

\author{
(online) $=$ ISSN $2285-3642$ \\ ISSN-L = $2285-3642$ \\ Journal of Economic Development, Environment and People \\ Volume 4, Issue 3, 2015 \\ URL: $\underline{\text { http://jedep.spiruharet.ro }}$ \\ e-mail: office jedep@spiruharet.ro
}

Active policy on the labour market includes measures, programs and plans aimed to return the unemployed to work for their inclusion in the workplace. Therefore, it provides [4]:

- preventive measures of employment services together with employers for reorientation and retraining of the staff of enterprises and organizations engaged in structural adjustment of production;

- actively seeking a job and job placement in accordance with the profession, personal experience and inclinations of the worker;

- measures in support of self-employment;

- professional counseling to those who want to discover their own company;

- non-monetary forms of support for small and family business.

Thus active policy aimed at strengthening the competitiveness of the workforce, supporting all forms of individual employment, including family businesses and farming. Part of the active policy on the labour market is the support of the unemployed in its active search of methods for inclusion in employment, which would enable it to provide financial yourself and your family with income and other means of subsistence.

\title{
2. Contemporary conditions of labour market and policy development in Bulgaria
}

Existing conditions for full employment enable almost all countries to focus on the issue of labour efficiency, the behaviour of participants in the labour process, the attitude towards work. After 70 years in the world of substantial changes in the economic and social life that have an impact on labour relations, and the strict sense of the term. Widening gaps between demand and supply of labour brought forward the concept of a labour market in which the main focus is the relationship between employers and workers.

Based on the current status, trends and prospects of the labour market within the European area identify the main challenges of employment policy in the field of human resources [4-6]:

- Substantial reduction in employment and increase in unemployment during the economic crisis, especially among disadvantaged groups in the labour market, especially young people, increasing inactive;

- Delayed exit and very limited creation of new jobs;

- Low educational qualification level of jobseekers and low mobility in a segmented labour market; mismatches in supply and demand for labour in terms of professional qualification structure of the workforce;

- The need for improving the quality of jobs and increase labour productivity, which will lead to increased incomes and expanding domestic consumption;

- The existence of unregulated employment and violations of labour law;

- Significant regional differences in employment and unemployment.

Some possible threats are identified improving the match between demand and supply of labour and the functioning of the labour market:

- Belated exit from recession and weak economic growth in the EU and slow economic recovery, which together with insufficient competitiveness of the economy, are a threat to the creation of more and better jobs. 


\author{
(online) $=$ ISSN $2285-3642$ \\ ISSN-L = $2285-3642$ \\ Journal of Economic Development, Environment and People \\ Volume 4, Issue 3, 2015 \\ URL: $\underline{\text { http://jedep.spiruharet.ro }}$ \\ e-mail: office jedep@spiruharet.ro
}

- Globalization, which hides risks associated with job losses, outsourcing of economic activities and loss of income for certain professions, regions and sectors.

- Unfavorable demographic trends - by reducing the number and aging workforce, which limited the supply of labour. Deterioration of the labour force due to the exit of skilled labour and the influx of low-skilled, low education. Influencing are also the external migration, and the gap in the quality and relevance of education, low participation of the population in lifelong learning; regional disparities and imbalances, limited mobility and more.

At the same time there are certain favourable conditions as the financial stability of the country and significant financial resources under operational programs and other EU programs.

Bulgaria and other socialist countries, subject to the notion of "full employment" more than half a century, now suffer the serious consequences of transition and restructuring of the economy that are the most severe in the area of employment. Bulgaria was relatively unprepared to meet the challenges of the market economy in this area and the lack of public attitudes for more personal activity, personal responsibility and entrepreneurship. Expectations for change are linked again and primarily the role of the state.

Employment policy pursued in the country complies with European documents in the field of employment and human resources development: the European Employment Strategy, Strategy "Europe 2020", the Employment Guidelines of the European Commission. The actions of the labour market in accordance with the requirements and recommendations of the International Labour Organisation (ILO), Organisation for Economic Cooperation and Development (OECD) and other international organizations. Updated Employment Strategy 2013 - 2020 adoption foresees also implementation of the Council Decision of 21 October 2010 on guidelines for the employment policies of the Member States which are in force in 2013, namely:

Guideline 7: Higher participation of women and men on the labour market, reducing structural unemployment and improving the quality of jobs.

Guideline 8: Developing a skilled workforce responding to the needs of the labour market and promote lifelong learning.

Guideline 9: Improving the quality and effectiveness of education and training at all levels and increasing the number of students in tertiary or equivalent education.

Guideline 10. Promoting social inclusion and combating poverty.

Updated Employment Strategy is in line with the strategy "Europe 2020" and its three complementary priorities in terms of economic growth, which should be intelligent (building an economy based on knowledge and innovation), sustainable (promoting more greener and more competitive economy with more efficient use of resources) and inclusive (stimulating the economy with high employment levels, leading to social and territorial cohesion).

The vision of the updated Employment Strategy 2013 - 2020 is defined as: ensure conditions and opportunities for improving the quality of the workforce and increasing employment in the economy of smart, sustainable and inclusive growth to raise living standards and promote social inclusion . 


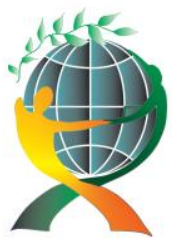

\author{
(online) $=$ ISSN $2285-3642$ \\ ISSN-L = 2285 - 3642 \\ Journal of Economic Development, Environment and People \\ Volume 4, Issue 3, 2015 \\ URL: $\underline{\text { http://jedep.spiruharet.ro }}$ \\ e-mail: office jedep@spiruharet.ro
}

Along with the main target for employment, Bulgaria has defined two sub-goals in priority areas of development of the labour market [7]:

- Achievement of employment among older people (aged 55-64) from 53\% in 2020.

- Reduce youth unemployment rate for the age group 15-29 to 7\% in 2020.

Objectives in the updated Employment Strategy 2013 - 2020, were in line with the Global Employment Strategy, developed by the ILO, as well as key areas of impact of the employment strategy for the ILO Decent Work.

The vision of the updated Employment Strategy 2013 - 2020 has been designated, taking into account a number of factors. EU membership and the need for full integration of the Bulgarian economy in the common market requires continued reforms to achieve set criteria for higher competitiveness and longterm ability to meet the changes. Changes in the labour market require provision of skilled and motivated workforce that will contribute to achieve smart, sustainable and inclusive economic growth and higher productivity.

The main priorities of the updated Employment Strategy 2013 - 2020 include [7]:

1. Increasing employment in a smart, sustainable and inclusive growth, which implies the presence of sufficient quality workforce with the knowledge and skills according to the needs and requirements of jobs and the capacity for higher productivity.

This workforce is formed for an extended period and provided that the access to education and training is improved in time, trainees are largely successful, and those who left early education system are included in the appropriate forms for employment and training. Quality workforce is the product of a quality and efficient system of education and training and throughout the life of man, a system which is necessarily linked to the needs of the economy and employers. Quality workforce is not an end, it is motivated to work on productive jobs, to create high added value intellectual work with the application of new information technologies, with demands for innovation and creativity. In turn, the economy needs to create such jobs. For low-skilled it is important to be trained for training and acquisition of skills for a productive work.

2. Increasing labour supply is a key priority not only for the high inactivity of the working population, but also because of the demographic problems and the need for a higher volume of GDP produced in domination of still extensive development factors. All this requires the active behaviour on the labour market of job seekers and the development of employment services; activation of discouraged and inactive, unemployed from vulnerable groups; creating conditions for reconciling work and family life and providing equal opportunities. Labour supply increases when employment provides enough income linked to individual productivity of labour, education and training of people. Workforce in turn must be sufficiently mobile in terms of flexibility and employment security. A prerequisite for a complete working life is good health and preservation of the capacity and the higher age groups. Priority is also increasing the employability of disadvantaged groups on the labour market, especially young people, long-term unemployed, unemployed Roma, people with disabilities.

3. The slow recovery from the crisis and job losses even in positive GDP growth means that job creation cannot be left solely to market forces. A targeted support for increasing labour demand especially in the priority for economic development sectors with high added value, such that deliver smart sustainable growth, to increase local and foreign investments to reduce regional disparities in employment and market 


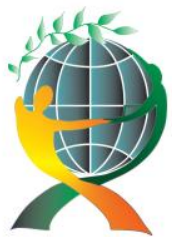

\author{
(online) $=$ ISSN $2285-3642$ \\ ISSN-L = $2285-3642$ \\ Journal of Economic Development, Environment and People \\ Volume 4, Issue 3, 2015 \\ URL: http://jedep.spiruharet.ro \\ e-mail: office jedep@spiruharet.ro
}

labour; for targeted support for small and medium-sized enterprises; employment creation of "green jobs"; development of a competitive and resource-efficient economy, increased factor productivity, increase employment of "white jobs", including in the field of social services.

The object of the updated strategy are a wide range of individuals, institutions and organizations that participate on the labour market. In this sense essential to the actions of its implementation is ensuring a balance between their interests, rights and responsibilities. Increasing attention will be given not only the unemployed persons from vulnerable groups, and other groups seeking employment (employed who want to change jobs or to work extra, students, retired) employees who need training and more. Crucial role is that of the institutions of the labour market, the capacity of which depends on improving the overall functioning of the whole system of employment and more effective and efficient use of available resources.

To the subjects of policy of employment in Bulgaria must be mentioned: the state and its specialized agencies: the Employment Agency of the Ministry of Labour and Social Policy, the National Council for Tripartite cooperation representing workers' organizations, employers' organizations, the Agency for Social Assistance of the Ministry of Labour and Social Policy; regional level - regional governors, municipalities, regional employment offices and job centers. These entities are engaged in institutionalized relations "regarding labour" and those between employers and workers. Institutionalized subjects can occur as legalized private agencies and bureaus for employment, some non-governmental organizations among its other social functions to have intermediary business of finding employment for persons at risk groups and participate in the implementation of projects for training, qualification and retraining.

Bulgarian employment agency (EA) [1, 2] aims to implement the state policy on employment promotion and protection of the labour market, vocational guidance, adult education, and to perform intermediary employment services to increase economic activity and employment potential of the population, by increasing employment and reducing unemployment. The main functions of the employment agency are registering vacancies and those actively seeking employment mediation services for employment. It engages with joint participation of municipalities and employers in the development of socially beneficial for the city and state activities and participation in the development and implementation of programs and measures for employment and training aimed at specific groups of unemployed people who for various reasons are hard adaptable to labour market. The agency participates in performance, either alone or jointly with other bodies or organizations, projects and programs in the areas of employment, vocational education and training, social integration, financed by the funds of the European Union or other international organizations, including and with the participation of Bulgarian resources. It also deals with the protection and preservation of employment, organizing qualification and motivation training of unemployed and employed, brokering employment of Bulgarian citizens abroad and foreigners in Bulgaria and analysing supply and demand in the labour market and forecasting possible changes.

Reform of administrative services in the Employment Agency begins with the preparation of analysis of the services provided by the Agency departments covering its overall activity. Main conclusions of the analysis are that there is a need of [3]:

- A reform in the administrative services, substantiated by:

- New national social strategy;

- Changes in the market environment; 


\author{
(online) $=$ ISSN $2285-3642$ \\ ISSN-L = $2285-3642$ \\ Journal of Economic Development, Environment and People \\ Volume 4, Issue 3, 2015 \\ URL: http://jedep.spiruharet.ro \\ e-mail: office jedep@spiruharet.ro
}

- New customer needs;

- Increased requirements for quality of service;

- Achieve the standards and characteristics of the administrations of the EU.

- Changes in external environment

- Significant changes in the structure of unemployment;

- A growing mismatch between the qualifications of job seekers and employers' requirements.

- Changes in domestic environment

- Rugged, but insufficient effective operation of the EA, despite heavy workload of the employees in the system;

- Insufficient good image of LOD for employers and job seekers;

- Increased expectations from the public and from the government for an active role of the EA in the labour market.

Main criticisms of the work of LOD are focused on:

- Bureaucracy, tardiness citizens;

- unequal treatment of individuals;

- Giving information only "internal" people;

- Indifference or mistreatment of employees;

Subjects to change are defined as:

- The way EA provides services- workflows;

- The culture of responsibility and decision-making;

- Work environment;

- Knowledge, skills, behaviours and attitudes of employees.

A very important point is that reform to improve administrative services in the EA does not require a change in legislation - the Law on Employment Promotion and other regulations.

The next step is the approval of the vision and objectives of the organizational change of the Employment Agency and the specific services that its departments provide.

Employment mediation services include:

- information and / or advice to job seekers and employers;

- psychological assistance to job seekers;

- referral to appropriate programs and measures for employment and training;

- referral to adult education;

- guidance and support for employment, including in another location in the country or in other countries. 


\author{
(online) $=$ ISSN $2285-3642$ \\ ISSN-L = $2285-3642$ \\ Journal of Economic Development, Environment and People \\ Volume 4, Issue 3, 2015 \\ URL: $\underline{\text { http://jedep.spiruharet.ro }}$ \\ e-mail: office jedep@spiruharet.ro
}

Directorate "Labour Office" (LOD) is one of the main intermediaries on the labour market. Except that, LOD performs tasks in regulating the labour market, i.e. performs activities on the realization of social strategies and policies. In this capacity, LODs in the country perform the following functions [2, 3]:

- Register job seekers, according to the Law on Employment Promotion (LEP) and its Implementing Regulations and develop an action plan of each registered unemployed person;

- Provide job seekers in compliance with the LEP and the related regulations about: the services provided by the labour office, conditions and procedures for their use; vacant jobs; programs and measures for employment and training, as well as other information from the competence of the Labour Office;

- Implementation of mediation information and employment in Bulgaria and in the Member - States of the European Union, European Economic Area and Swiss Confederation, guidance / information, advice and counselling /; psychological support; adult education; inclusion in programs and measures for employment and training; support to start own business; Information on procedures for operating schemes under international programs and projects, incl. Operational Programme "Human Resources Development";

- Advising on employment opportunities for Bulgarian citizens abroad, incl. use of the network EURES, and foreign nationals in the Republic of Bulgaria and intermediary business in implementation of international agreements for the exchange / export of labour and intermediary contracts concluded by the Employment Agency with foreign employers or licensed intermediaries;

- Provide employers in compliance with the LEP, the Law on protection of personal data and related regulations information for: those seeking work; programs and measures to preserve and promote the employment and training of staff; the rights and obligations under the mass dismissal of employees; mediation to hire labour; inclusion in programs and measures for employment and training; preferences while maintaining and / or increasing employment; preferences for internship and / or apprenticeship; incentives to promote territorial mobility of employees;

- Participate in the survey of the training needs for acquiring professional qualification and acquisition and development of key competencies;

- Perform duties by informing in mass layoffs and teams participate in the drafting of the necessary measures in mass layoffs;

- Carry out an information exchange with other LOD for the announced jobs;

- Provide the Agency for Persons with Disabilities with the received from employers information about jobs for people with disabilities on the grounds of the Implementing Regulations of the Law for the integration of people with disabilities;

- Prepare opinions on applications for issuance of work permits to foreign nationals in the Republic of Bulgaria;

- Record short-term employment of foreign nationals, according to the Ordinance on the terms and conditions of the issuance, denial and revocation of work permits to foreigners in the Republic of Bulgaria;

- Participate in the development of regional and sectoral programs for employment and training in the part containing actions in the active employment policy; 


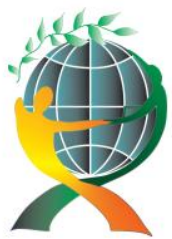

\author{
(online) $=$ ISSN $2285-3642$ \\ ISSN-L = $2285-3642$ \\ Journal of Economic Development, Environment and People \\ Volume 4, Issue 3, 2015 \\ URL: $\underline{\text { http://jedep.spiruharet.ro }}$ \\ e-mail: office jedep@spiruharet.ro
}

- Participate in the implementation of national, regional and sectoral programs for employment and training;

- Gives opinions and propose for approval by the Minister of Labour and Social Policy of regional programs for training and employment, including literacy programs, training and employment;

- Carry out activities for the organization and implementation of vocational guidance and training for adults;

- Operate programs and projects funded by the European Union and other international sources;

- Carry out activities and programs addressing the Social Investment Fund to provide employment services, training for acquiring qualification, support for small business, local communities, etc.;

- Prepare a draft Action Plan;

- Implement the approved Action Plan;

- Prepare periodic and annual reports on implementation of the Action Plan;

- Develop forecast performance, and if necessary make a proposal to adjust the approved Action Plan;

- Develop, where appropriate, action plans for the implementation of specific tasks;

- Participate in the preparation of the annual activity plan of the Employment Agency, as a member of the network EURES;

- Prepare periodic and annual reports on the implementation of those included in the approved Action Plan programs and measures to promote employment and training, vocational guidance and training for adults;

- Collect, process, store and provide statistical information on the state of employment and unemployment on the territory they serve. Exchange information with other administrations;

- Perform duties in accordance with signed agreements and protocols on cooperation with agencies, organizations and social partners related to the provision of employment services;

- interact with the "District Labour Inspectorate" in connection with the Agreement signed for coordination, cooperation and collaboration between the Executive Agency "General Labour Inspectorate" and Employment Agency;

- Participate in the operation and development of the automated information system of the Employment Agency;

- Prepare analyses on the status and trends in the local labour market and unemployment projections;

- Engage in research and observation of the labour market;

- Organize reception of citizens and provide answers on applications, complaints and reports of citizens within the framework of their competences;

- Organize, coordinate and participate in the implementation of activities in service of job seekers and employers to the Labour Office revealed outsourced jobs;

- Perform quality delivery of services; 


\author{
(online) $=$ ISSN $2285-3642$ \\ ISSN-L = $2285-3642$ \\ Journal of Economic Development, Environment and People \\ Volume 4, Issue 3, 2015 \\ URL: $\underline{\text { http://jedep.spiruharet.ro }}$ \\ e-mail: office jedep@spiruharet.ro
}

- Support the organization of workshops, information days, job fairs and events related to the tasks of EURES;

- Organize regular press conferences to inform the public about the activities of the Labour Offices;

- Apply measures to prevent and combat corruption.

In response to the priorities of the social policy of the country, expressed in the activities in competent institutions, is the need for new approaches and actions for effective management of social processes tailored to the dynamic social environment on the basis of economical, effective, efficient transformation of extremely limited budgetary resources in social skills for active social policy.

\title{
3. Application of a process model in the work of the Directorates "Labour office"
}

The introduction of a process model of service provision in the Labour Office is a versatile tool for better management of activities in different LOD by providing the necessary human resources and its use in the most efficient manner. The model is created in electronic form (Excel-tables), which allows developing of various scenarios based on different starting conditions and assumptions in different LOD [6].

The main processes (Table 1) [3]:

1. Information;

2. Registration;

3. Placement;

3.1. Placement - working with job seekers;

3.2. Placement - selection and selection;

3.3. Placement - working with employers;

4. Vocational education and training;

5. Implementation of programs and measures;

6. Termination and renewal of registration;

7. Management of suggestions, complaints and signals;

8. Psychological support

- Describe one or more activities in all the main processes - in this sense technology to work around the process or individual activity in the process;

- Contain applied to each activity or whole process forms, questionnaires, etc.;

- Guidance technology work and sequence of activities and operations;

- Visualize customer service;

- Assist the interaction between experts in different processes or workers in various activities of the same process;

- Provide space for creativity when working with clients;

- Assist to avoid duplication of data collection and duplication of additional activities and forms;

- Create conditions for regulating service time; 


\author{
(online) $=$ ISSN $2285-3642$ \\ ISSN-L = 2285 - 3642 \\ Journal of Economic Development, Environment and People \\ Volume 4, Issue 3, 2015 \\ URL: http://jedep.spiruharet.ro \\ e-mail: office jedep@spiruharet.ro
}

- Support the creation of knowledge and expectations for uniformity of service to different customer characteristics;

- Create confidence of specialists;

- Clients learn mode of operation, which improves relations (reduced stress);

- Place on a standardized service, which is the first condition for providing quality services.

Table 1. Basic processes in the Directorate "Labour Office"

\begin{tabular}{|c|c|}
\hline Process & Goals \\
\hline Information provision & $\begin{array}{l}\text { - Ensure equal access to information and services and provide different access } \\
\text { channels. } \\
\text { - } \quad \text { Fast and quality customer service by providing a clear, easy to understand, } \\
\text { complete and accurate information and explanations. } \\
\text { - Uniform flow distribution os persons seeking for a job and directing them to } \\
\text { obtain services to staff competence. } \\
\text { - Fostering independent work habits and search of useful information through } \\
\text { various information sources. } \\
\text { - Directing the attention of customers to use alternative sources of information } \\
\text { (web-site, e-mail, kiosks, town halls, libraries, etc.). }\end{array}$ \\
\hline Registration & $\begin{array}{l}\text { - } \\
\text { - } \\
\text { Fegistration of the individual for the subsequent use of services by LOD. } \\
\text { accurate information, explanations and forms necessary for the registration of persons. } \\
\text { - } \quad \text { Collecting complete and accurate information about the persons seeking for jobs } \\
\text { - } \quad \text { Faster inclusion of seeking jobs on the labour market, by offering suitable } \\
\text { vacancies on the day of registration. } \\
\text { - } \quad \text { Reduce unevenness of the flow through even distribution of the various } \\
\text { contingents for subsequent visits to labour brokers. }\end{array}$ \\
\hline $\begin{array}{l}\text { Placement - working } \\
\text { with job seekers }\end{array}$ & $\begin{array}{l}\text { Provide information on available vacancies in order to quickly realize on the } \\
\text { labour market. } \\
\text { - } \quad \text { Display the characteristics of the seeking jobs in order to improve and facilitate } \\
\text { the selection and recruitment vacancies. } \\
\text { - Increase the number of hired throughout unemployed persons by encouraging } \\
\text { them to participate actively in the labour market. } \\
\text { - Supporting employment of the unemployed, by assessing the shortage of skills, } \\
\text { counseling and referral to training for acquiring professional qualification, technical or } \\
\text { social skills, and skills for independent job search. } \\
\text { - Supporting young people under } 29 \text { years of age for employment and / or inclusion } \\
\text { in the training. } \\
\text { - } \quad \text { Development of an individual plan for finding work for the unemployed in an } \\
\text { optimally short term. }\end{array}$ \\
\hline $\begin{array}{l}\text { Placement - working } \\
\text { with employers }\end{array}$ & $\begin{array}{l}\text { - } \\
\circ \quad \text { Implementing the scope of employers using the services of directorates "Labour" by: } \\
\text { that providing employment for job seekers; }\end{array}$ \\
\hline
\end{tabular}




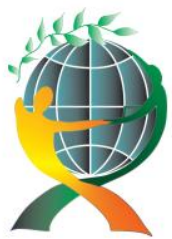

\author{
(online) $=$ ISSN $2285-3642$ \\ ISSN-L = 2285 - 3642 \\ Journal of Economic Development, Environment and People \\ Volume 4, Issue 3, 2015
}

URL: http://jedep.spiruharet.ro

e-mail: office jedep@spiruharet.ro

\begin{tabular}{|c|c|}
\hline & $\begin{array}{l}\text { Preliminary analysis of business performance and segmentation, depending on } \\
\text { their economic activity and capacity for announcement of vacancies in the LOD. } \\
\text { - } \quad \text { Increasing vacancies in order to more opportunities for job seekers through: } \\
\text { Active contacts with employers announcing vacancies; } \\
\text { Proactive contacts with employers and proposing appropriate profiles of job } \\
\text { seekers, even without the vacant job. } \\
\text { - Achieving full specification of vacancies for subsequent fast and qualitative } \\
\text { selection and recruitment of job seekers. }\end{array}$ \\
\hline Psychological support & $\begin{array}{l}\text { - Applying individual approach to job-seekers to overcome the psychological } \\
\text { obstacles in search of employment. } \\
\text { - Adapting to the demands of the labour market of job seekers by increasing their } \\
\text { motivation to actively search for employment and the formation of presentation skills } \\
\text { when applying for vacancies. } \\
\text { - Supporting employment intermediaries for quality service to employers in the } \\
\text { selection for appointment to vacant jobs. } \\
\text { - } \quad \text { Support communicative competence consulting the employees of the LOD. }\end{array}$ \\
\hline $\begin{array}{l}\text { Implementation of } \\
\text { programs / projects for } \\
\text { employment and } \\
\text { training }\end{array}$ & $\begin{array}{l}\text { - Provide employment to unemployed persons in an disadvantaged position on the } \\
\text { labour market. } \\
\text { - Increasing the employability of unemployed people by involving them in programs for } \\
\text { employment and training. } \\
\text { - Increasing the number of the hired among unemployed persons through their } \\
\text { inclusion in existing employment programs and training. } \\
\text { - Helping the unemployed to start their own business. } \\
\text { - Encouraging employers to participate in existing programs / projects for employment. } \\
\text { - Acquisition of permanent work habits by job seekers, reducing their dependence on } \\
\text { the social assistance system and their return to the labour market. }\end{array}$ \\
\hline $\begin{array}{l}\text { Implementation of } \\
\text { measures for } \\
\text { employment and } \\
\text { training }\end{array}$ & $\begin{array}{l}\text { - Methodological and technological unification of LOD's activity related to the } \\
\text { implementation of active employment measures: } \\
\text { - Inclusion of employers in training measures and employment; } \\
\text { - } \quad \text { Increasing the employability of the unemployed through participation in active } \\
\text { measures for training and employment; } \\
\text { - Providing employment to unemployed persons disadvantaged on the labour } \\
\text { market; } \\
\text { - } \quad \text { Pncouraging entrepreneurship among the unemployed; } \\
\text { place. } \\
\text { - } \\
\text { - } \quad \text { Impromoting mobility of unemployed persons with a view to finding a job in another } \\
\text { - } \quad \text { Improving the quality and efficiency of services for the unemployed and } \\
\text { employers. }\end{array}$ \\
\hline $\begin{array}{l}\text { Termination of } \\
\text { registration }\end{array}$ & $\begin{array}{l}\text { - Fast and quality service to job seekers by providing a clear, easily understood, } \\
\text { complete and accurate information, explanations and forms. } \\
\text { - } \quad \text { Correct application of the provisions of the Law on Employment Promotion and } \\
\text { the Implementing Regulations of the Law on Employment Promotion. }\end{array}$ \\
\hline $\begin{array}{l}\text { Management of } \\
\text { proposals, alerts and }\end{array}$ & $\begin{array}{l}\text { Responsibility of the administration to the public and the proposals and signals, } \\
\text { legality and appropriateness of decisions. }\end{array}$ \\
\hline
\end{tabular}




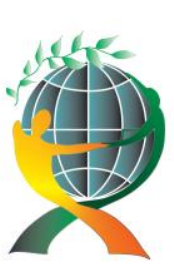

\author{
(online) $=$ ISSN $2285-3642$ \\ ISSN-L = 2285 - 3642 \\ Journal of Economic Development, Environment and People \\ Volume 4, Issue 3, 2015
}

URL: http://jedep.spiruharet.ro

e-mail: office jedep@spiruharet.ro

\begin{tabular}{|l|lr|}
\hline complaints & $\begin{array}{ll}\bullet & \text { Fast and quality customer service by providing information, explanations and } \\
\text { advice. } & \\
- & \text { Establishing mechanisms for customer feedback and changes in accordance with } \\
\text { those comments. } & \\
- & \text { Encouraging customers to improve administrative services. }\end{array}$ \\
\hline
\end{tabular}

Initial conditions are bound by the policies and objectives of the Employment Agency. To allow maximum fine, the prerequisite to use the model input data is to comply with the National Employment Plan for the current year. Assumptions related to changes in how the Labour Office and the implementation of the new process model. Much of the planned implementation activities require additional time and effort. In order to achieve better performance of the LOD, the new process model should be provided with the necessary capacity.

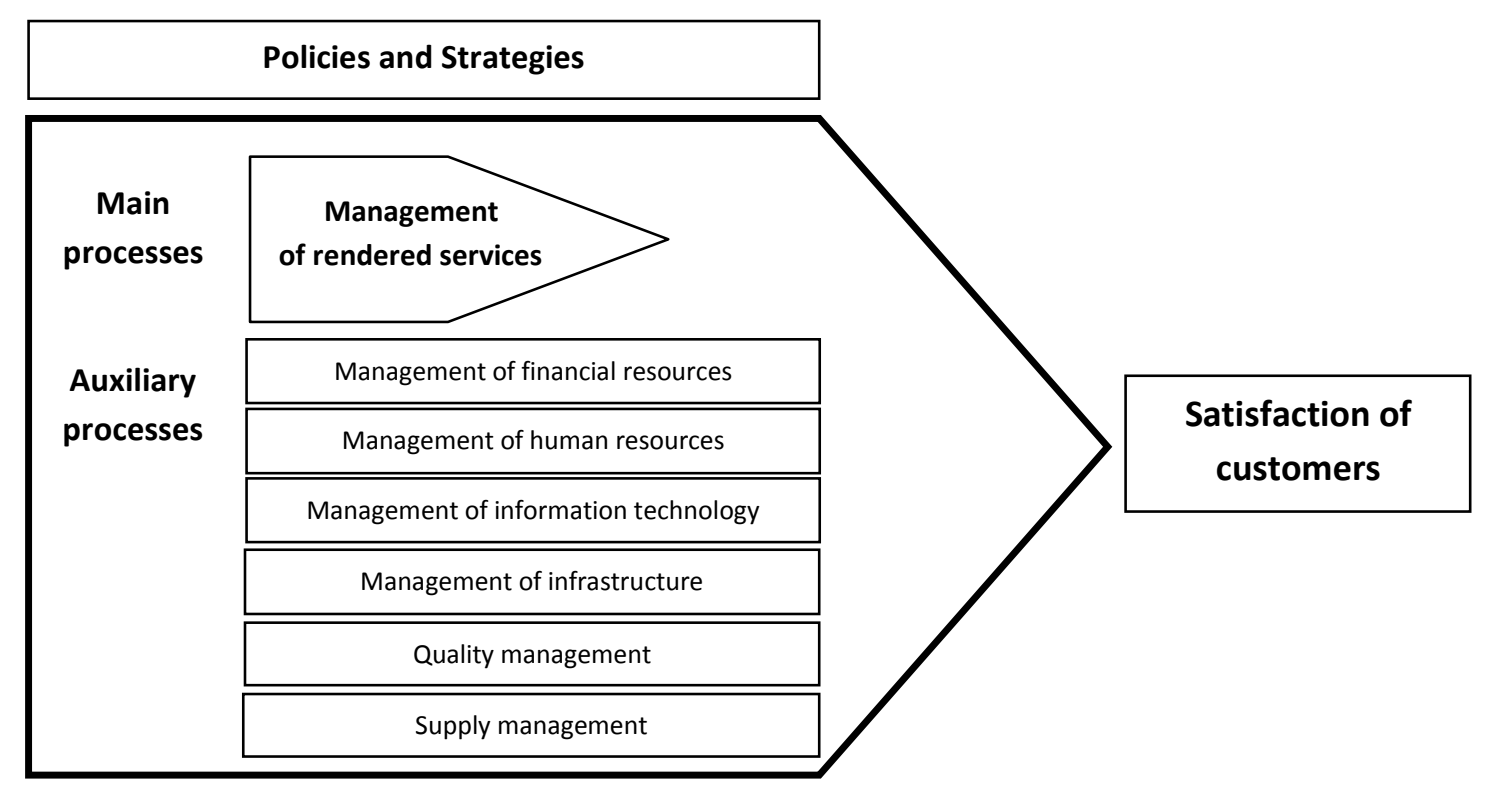

Figure 1. The new process model [3]

The processes outlined above, can develop and be improved to varying degrees. In order to achieve results as quickly as possible, however, it makes sense to focus on the following four specific areas called "four levers of change".

The change embraces:

- Improving the key processes;

- Feedback;

- Public Relations;

- Interior design;

- Location of access. 


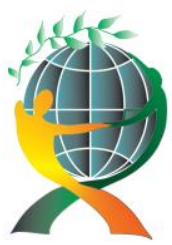

\author{
(online) $=$ ISSN $2285-3642$ \\ ISSN-L = $2285-3642$ \\ Journal of Economic Development, Environment and People \\ Volume 4, Issue 3, 2015
}

URL: http://jedep.spiruharet.ro

e-mail: office jedep@spiruharet.ro

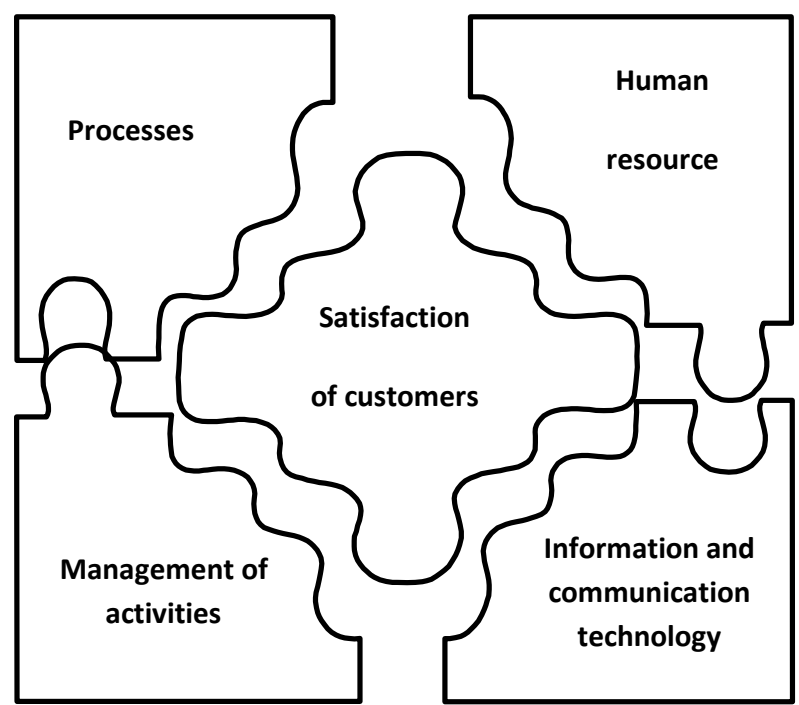

Figure 2. The four levers of change [3]

During the creation of the algorithm the following logical framework is used [6]:

- Initial starting point for the created algorithm are the results to Employment Agency should achieve within the strategic plan or a budget year (Action Plan for Employment). These results represent the concretization of the agency's mission and its objectives, which are generally formulated as: reducing unemployment and increasing employability of the workforce to the requirements of the labour market; achieve financial sustainability in the provision of services by ensuring sufficient resources and proper timing and regions; achieving the correct and proper balance between the benefits of services and for providing their costs; customer satisfaction of services rendered;

- These strategic objectives are defined with specific quantitative and qualitative indicators, which must be guaranteed output of the system such as achieving a certain amount of services rendered, number of clients served, limits used for the implementation of specific programs and measures for employment, etc.; achieve a certain amount of service through fixed amounts of expenditure in legislation and defined optimal costs;

- To achieve revenues from fixed fees paid services.

The created algorithm to determine the necessary resources, their costs and their allocation to the relevant processes is in the widespread Excel format, making it easy to implement and to simulate scenarios. This supports a reasonable budget preparation and flexible adaptation of resources to the LOD requirements of the labour market during the budget year.

The algorithm fully reflects the way the services are rendered. As services are realized through workflow organization, the algorithm is based entirely on the model for determining the current and future capacity. Information on the detailed operation of the algorithm is available in each table.

At the highest level created algorithm has the following main components:

- Human resources and costs; this includes direct expenditures of time and labour services-wage labour costs for administrative services and the cost of staff training; 


\author{
(online) $=$ ISSN $2285-3642$ \\ ISSN-L = 2285 - 3642 \\ Journal of Economic Development, Environment and People \\ Volume 4, Issue 3, 2015 \\ URL: http://jedep.spiruharet.ro \\ e-mail: office jedep@spiruharet.ro
}

- Material resources and costs; It includes direct material costs for services and indirect material costs for services;

- Capital expenditure;

- Costs for financing programs, measures for employment, training and qualification of projects and business benefits.

Table 2. Model for determining the necessary resources [6]

\begin{tabular}{|c|c|c|c|}
\hline Input & Process & Ouput & Result \\
\hline 1 & 2 & 3 & 4 \\
\hline Physical resources & Productiveness & Quantity & $\begin{array}{l}\text { Fulfill the mission and achieve } \\
\text { the objectives }\end{array}$ \\
\hline quantity & $\begin{array}{l}\text { Expenditures per } \\
\text { service unit }\end{array}$ & Quality & Financial sustainability \\
\hline $\begin{array}{c}\text { quality } \\
\text { time schedule } \\
\text { value }\end{array}$ & Coefficients & $\begin{array}{c}\text { services } \\
\text { way of rendering } \\
\text { Cost }\end{array}$ & $\begin{array}{l}\text { Expenditures / Benefits } \\
\text { Satisfaction of customers }\end{array}$ \\
\hline & & Price (fee) & \\
\hline $\begin{array}{c}\text { Financial resources } \\
\text { quantity } \\
\text { time schedule }\end{array}$ & & Satisfaction of customers & \\
\hline \multicolumn{4}{|c|}{$\begin{array}{l}\text { Logic scheme of the model to determine the resources is: } \\
\text { 1. } \\
\text { 2. The results are determined (column } 4 \text { ). } \\
\text { 3. } \\
\text { 4. The processes by which services are rendered are described and measured (column } 2 \text { ). } \\
\text { (column 1). }\end{array}$} \\
\hline
\end{tabular}

The main objective of the developed algorithm is to create a means of allocating costs to the basic services of the agency. This makes it easy to justify the resources required at different starting points as available capacity, existing and expected period of service, available resources, and to determine the value of each service.

By created algorithm can define and justify the following processes:

- To justify the necessary human, material, financial and information resources to provide services and objectives of the Agency;

- Identify factors for performance, economy and efficiency of activity of the Agency as clients served per time unit, unit cost of service, number of employees of 1,000 registered unemployed persons, number of employees to 100 in a job, etc., To serve as a set norms for the implementation of activities in the Agency;

- Monitor and control costs against services rendered to the Agency and undertake adjustments in case of market equilibrium between supply and demand of labour. 


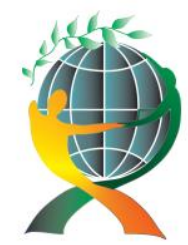

\author{
(online) $=$ ISSN $2285-3642$ \\ ISSN-L = 2285 - 3642 \\ Journal of Economic Development, Environment and People \\ Volume 4, Issue 3, 2015
}

URL: http://jedep.spiruharet.ro

e-mail: office jedep@spiruharet.ro

Table 3. Main differences between past and new work model [3]

\begin{tabular}{|c|c|c|}
\hline Process & Before & After \\
\hline Registration & $\begin{array}{l}\text { - Segmentation of job seekers is an } \\
\text { isolated case; } \\
\text { - Triple input of registration data; } \\
\text { - Availability of duplicate attributes in } \\
\text { the registration documents; } \\
\text { - Unable to direct the reopening of } \\
\text { the file in the case of re-registration; } \\
\text { - Loss of traceability for prior work } \\
\text { with job seekers. }\end{array}$ & $\begin{array}{l}\text { - Primary segmentation/ prioritization } \\
\text { of the contingent - integration with the } \\
\text { process "Placement"; } \\
\text { - Immediately supply of available } \\
\text { vacancies at registration and each } \\
\text { subsequent visit; } \\
\text { - Optimizing introduced-net } \\
\text { information by reducing the number of } \\
\text { data sets and repetitive details. }\end{array}$ \\
\hline $\begin{array}{l}\text { Training and } \\
\text { qualification }\end{array}$ & $\begin{array}{l}\text { - Mismatch between available skills of } \\
\text { job seekers and sought those of } \\
\text { employers; } \\
\text { - Campaign promoting the limits on } \\
\text { topics and allocation; } \\
\text { - Non-related to labour } \\
\text { intermediation forming groups for } \\
\text { training; } \\
\text { - Lack of specific commitments of job } \\
\text { seekers in connection with new skills } \\
\text { and qualifications; } \\
\text { - A separate tender procedure for } \\
\text { each theme-a waste of time. }\end{array}$ & $\begin{array}{l}\text { - Focus on shortage of skills in the } \\
\text { labour market; } \\
\text { - Dynamic planning and organizing } \\
\text { the trainings; } \\
\text { - Diversification of forms and training } \\
\text { opportunities; } \\
\text { - Greater freedom and regional } \\
\text { diversity of the training; } \\
\text { - Monitoring the implementation of } \\
\text { the commitments of the person in } \\
\text { connection with newly acquired skills } \\
\text { and qualifications. }\end{array}$ \\
\hline $\begin{array}{l}\text { Programs and } \\
\text { measures }\end{array}$ & $\begin{array}{l}\text { - Variety of measures and programs } \\
\text { can not effectively serve the existing } \\
\text { available capacity; } \\
\text { - Premature financial support of } \\
\text { established strategic programs; } \\
\text { - The development and launch of new } \\
\text { measures and programs is not } \\
\text { accompanied by the closure or change in } \\
\text { such with a weak social impact. }\end{array}$ & $\begin{array}{l}\text { - Participation of experts from labour } \\
\text { offices in the development of new } \\
\text { programs; } \\
\text { - Preliminary testing programs; } \\
\text { - Timely financial, informational and } \\
\text { methodological provision of programs; } \\
\text { - Optimizing existing portfolio of } \\
\text { measures and programs to focus on } \\
\text { those with the greatest social impact; } \\
\text { - Dynamic management and change } \\
\text { of the existing portfolio of measures and } \\
\text { programs to reflect changes in the } \\
\text { contingent. }\end{array}$ \\
\hline Placement & $\begin{array}{l}\text { - Lack of proactive search for other } \\
\text { sources of vacancies advertised outside } \\
\text { in the LOD; } \\
\text { - Lack of segmentation of employers; } \\
\text { - Lack of proactive management of } \\
\text { relationships with employers; } \\
\text { - Lack of active management and } \\
\text { detailed specification of registered }\end{array}$ & $\begin{array}{l}\text { - Better knowledge and specifying the } \\
\text { needs and requirements of employers; } \\
\text { - Offered vacancies available } \\
\text { whenever a visit of a job seekers; } \\
\text { - Secondary segmentation of the } \\
\text { contingent; } \\
\text { - Better knowledge and specification } \\
\text { of owned and missing qualities of each }\end{array}$ \\
\hline
\end{tabular}




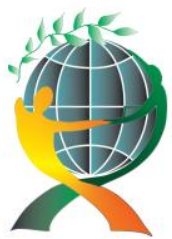

\author{
(online) $=$ ISSN $2285-3642$ \\ ISSN-L = 2285 - 3642 \\ Journal of Economic Development, Environment and People \\ Volume 4, Issue 3, 2015
}

URL: $\underline{\text { http://jedep.spiruharet.ro }}$

e-mail: office jedep@spiruharet.ro

\begin{tabular}{|c|c|c|}
\hline & $\begin{array}{l}\text { vacancies; } \\
\text { - Recruitment and selection of } \\
\text { appropriate job seekers on formal } \\
\text { grounds; } \\
\text { - Lack of opportunity to sort } \\
\text { candidates on key characteristics; } \\
\text { - Outdated nomenclature of } \\
\text { professions and levels of education; } \\
\text { - Establish and maintain relationships } \\
\text { with employers only in relation to their } \\
\text { activity; } \\
\text { - Formal and mechanical preparation } \\
\text { of the action plan of the job seekers. }\end{array}$ & $\begin{array}{l}\text { job seeker; } \\
\text { - Segmentation and active work with } \\
\text { employers; } \\
\text { - Actively seeking alternative sources } \\
\text { of job vacancies; } \\
\text { - More efficient selection of job } \\
\text { seekers respecting not only formal, but } \\
\text { also the specific requirements of } \\
\text { employers. }\end{array}$ \\
\hline $\begin{array}{l}\text { Administrative } \\
\text { processes }\end{array}$ & $\begin{array}{l}\text { - Weak discretion of the LOD; } \\
\text { - Existing culture of dependency in } \\
\text { the organization of work of the EA; } \\
\text { - A large number of informal } \\
\text { inquiries; } \\
\text { - Excessive detail of the package } \\
\text { standard reports; } \\
\text { - Insufficient active advertising and } \\
\text { information activities of the LO level. }\end{array}$ & $\begin{array}{l}\text { - Reduce the document turnover in } \\
\text { the system; } \\
\text { - Establish a culture of responsibility } \\
\text { and decision-making; } \\
\text { - Clearly specified the powers of the } \\
\text { directors of the LOD; } \\
\text { - Stimulating a certain discretion; } \\
\text { - Creating optimal management } \\
\text { processes to improve decision making. }\end{array}$ \\
\hline
\end{tabular}

It should be noticed however that there are a number of risks that may impede the proper definition of the capacity and use of the model in the Employment Agency. Among them the attention deserve the following [6]:

- Inefficient use of the model due to a misunderstanding of its basic parameters;

- Estimated capacity concerns only activities engaged in the fundamental processes of LOD. Some of them - participation in the development of new programs and measures, employee participation in the "import" and "export" of labour force participation in cooperation councils, etc., are not included and should be taken into account when calculating the total human resources needed for a LOD.

- Because of its specificity, activities associated with the implementation of resource processes of a LOD are not possible to be included in the scope of the model. Although decentralization initiative taken, outside the scope of the model remain the processes for managing information resources, supply management and all management activities of planning, communication, control and others.

Knowledge of risk situations is the basis of possible solutions for risk management in the implementation of the model and effective action for their prevention, or in case of failing - to bring them to reasonable limits.

Summarizing, the model to determine the required capacity as presented in the current paper is flexible tool for better management of activities in public employment services by providing the necessary human resources and their use in the most efficient manner. It provides the opportunity to develop different scenarios based on different starting conditions and assumptions in different labour offices in 


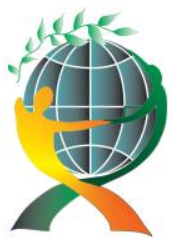

\author{
(online) $=$ ISSN $2285-3642$ \\ ISSN-L = $2285-3642$ \\ Journal of Economic Development, Environment and People \\ Volume 4, Issue 3, 2015 \\ URL: $\underline{\text { http://jedep.spiruharet.ro }}$ \\ e-mail: office jedep@spiruharet.ro
}

Bulgaria. Initial conditions are bound by the policies and objectives of the Employment Agency. Rationalization of management decisions to improve the effectiveness of social policy pursued by the directorates "Labour Office" created by a process model is based on defined processes, detailed metric measurement activities in the Employment Agency with a view to their standardization and determining necessary resource security processes, developing a model for determining the current and future capacity, an updated balance of time for each of the directorates "Labour Office" and algorithm for allocation of costs on basic processes of the Employment Agency. The algorithm fully reflects the way the services are functining. It is convenient to implement and simulate scenarios, thus supporting a reasonable budget preparation and flexible adaptation of resources to the requirements of the labour market during the budget year.

\title{
4. Conclusion
}

The dynamic changes of the social environment that determine the changes in attitudes and actions on labour markets and public service providers face policymaking in the field of employment in the coming years with serious challenges. Particular importance is assigned to the ability of the public employment services for vigorous action aimed at ensuring the maximum impact of policy on the labour market. Public employment services are expected to handle both current and future challenges. Rapid response to changing conditions and the combination of short-term interventions with sustainable solutions require flexibility, organizational response capability and creativity. Evolution from bureaucratic oriented organizations to more flexible, open, market-oriented networks and structures requires intellectual and cultural change as the business model and management, and individual ways of working.

Efficiency - economic and social, of functioning and developing social system is the result of the actions of all the factors of the system as a whole. Results of the creation of a model for effective social policy conducted on the labour market and employment define the basic processes in the implementation of the activities of the directorates "Labour Office". For this purpose, the activities and the steps contained in each of the processes carried out by the Labour Office should be carefully defines and specified. Optimizing and improving the quality of administrative services to improve the effectiveness of social policy pursued by the directorates "Labour Office" can be accomplished with the use of complex and systematic approaches that take into account available resources and capacity needed in the construction and improvement of new tools to streamline decisions, effective management and control.

\section{References}

[1] Bulgarian Employment Agency: http://www.az.government.bg/.

[2] Law on employment promotion (in power from 01.01.2002).

[3] Processes in labour mediation in Directorates "Labour office". Ministry of Labour and Social Policy of the Republic of Bulgaria. Center for human resources development and regional initiatives: http://distancelearning.ncpedu.net/.

[4] Terziev V. Impact of active social policies and programs in the period of active economic transformations in Bulgaria. "East West” Association for Advances Studies and Higher Education GmbH, Vienna, 2015.

[5] Terziev V., Dimitrova S. Social programming in the context of stimulating social activity and regulation of social 


\author{
(online) $=$ ISSN $2285-3642$ \\ ISSN-L = 2285 - 3642 \\ Journal of Economic Development, Environment and People \\ Volume 4, Issue 3, 2015 \\ URL: http://jedep.spiruharet.ro \\ e-mail: office jedep@spiruharet.ro
}

development through active policies. "East West" Association for Advances Studies and Higher Education GmbH, Vienna, 2015.

[6] Terziev, V. Challenges to social programming in the context of encouragement of social activity and regulation of social development through active policies, Ruse, 2015.

[7] Updated Employment Strategy of the Republic of Bulgaria 2013 - 2020. 